\title{
Recent landslides from Iași Metropolitan Area
}

\author{
Mihai NICULIȚĂ ${ }^{1 *}$, Valeriu STOILOV-LINU ${ }^{1}$, Nicușor NECULA $^{1}$ \\ ${ }^{1}$ Department of Geography, Faculty of Geography and Geology, Alexandru Ioan Cuza University of Iași, \\ Iași, Romania
}

Received 10 November 2018; Revised 10 December 2018; Accepted 15 December 2018

*Correspondence to: Mihai NICULIȚĂ, e-mail: mihai.niculita@uaic.ro

\begin{abstract}
The creation and analysis of landslide inventories is the basic approach for starting the landslide hazard to risk analysis chain analysis. In order to perform this kind of analysis for the Iași Municipality (North-eastern Romania) we created based on aerial imagery and LiDAR data a landslide inventory of the landslide events that happened in the last 100 years. In total, we identified and delineated 518 landslide events: 51.5\% translational slides, 19.7\% slumps (rotational slides), $17 \%$ flowslides and $11.8 \%$ flows. The majority $(74 \%)$ of the landslides events happened between 1956 and 1984, those before 1956 representing 16\%, while those triggered after 1984 representing $10 \%$. This situation reflects the very humid period between 1960 and 1990, when the majority of the landslide events were triggered. Beside the typology we have also identified the triggering factors and we can conclude that rainstorms coupled with previous rainy years were the main triggering factors, especially for Holocene old and relict landslides in areas with land use and anthropic disturbances created by the built up area expansion. The analysis of the landslide area frequency density is showing that the shape of the distribution curve is similar with what was reported in the literature, which is signaling that this inventory can be used further in landslide susceptibility modelling and validation. Further analysis of these events can also pinpoint scenarios for vulnerability and risk analysis.
\end{abstract}

KEYWORDS

recent landslides; Iași Municipality; North-eastern Romania

\section{Introduction}

The "landslide problem" (Brabb, 1991) require the study of landslides for the reduction of landslide risk. Landslide hazard is defined as the probability of landslide occurrence within a certain area and in a certain period (Varnes et al., 1984; Guzzetti et al., 1999; Guzzetti, 2006). A landslide inventory is a database (Carrara and Merenda, 1976; Guzzetti, 2006; Guzzetti et al., 2012) which describe in depth landslide events, their spatial and temporal location, and 
other attributes (their typology, causes and their effects). Landslide inventories represent the base information needed for landslide susceptibility modelling and validation (Carrara et al., 2003; Guzzetti, 2006) and for vulnerability scenario assessment (Alexander, 2005), crucial elements in the landslide hazard to risk chain (Reid, 1998; Crozier and Glade, 2005; van Westen et al., 2006).

We present a spatial database of landslides events from Iași Metropolitan Area, which happened during the last 100 years and which can be used for landslide susceptibility modelling and validation. For these events, the historical data, remote sensing data and the field evidences are enough to provide the full picture of the landslide morphology, the typology, the activity and to allow precise delineation. We argue that this database and its possible extension to include more events is of crucial importance for the landslide hazard and risk modelling for Iași County.

\subsection{Study area}

Iași Metropolitan Area (IMA) is located at the contact between the Central Moldavian Plateau and the Jijia Hills (Fig. 1). Beside Iași Municipality, IMA contains the territories of 18 communes $\left(1092 \mathrm{~km}^{2}\right)$ : Movileni, Popricani, Victoria, Rediu, Aroneanu, Lețcani, Valea Lupului, Holboca, Ungheni, Miroslava, Tomești, Țuțora, Mogoșești, Ciurea, Bârnova, Schitu Duca, Comarna and Prisăcani.

In the Jijia Hills the monoclinic structure and the homoclinal shifting of the river network (Jijia and Bahlui) influenced the development of a repetitive pattern of valleys and ridges (Fig. 2), with cuesta scarp slopes and cuesta dip slopes (Băcăuanu, 1968; Ioniță, 2000; Niculiță, 2011). The lithology (Fig. 3) is predominantly composed from siltstones and mudstones with sandy intercalations (Martiniuc et al., 1956; Brânzilă, 1999; Ionesi et al., 2005; Dill at al., 2011) from the Bessarabian Cryptomactra Clays Formation (under 125-150 m a.s.l.) and from mudstones and siltstones intercalated with sands from the Bessarabian Bârnova-Muntele Formation (230 m thick appearing over $125-150 \mathrm{~m}$ a.s.l.). The cuesta hills have a caprock of fluvial (2 to 5 m thick) and loess (5 to $25 \mathrm{~m}$ thick) deposits (Martiniuc and Băcăuanu, 1959; Martiniuc and Băcăuanu, 1966; Schram et al., 1977) and their absolute altitude do not exceed 220 m a.s.l. (Rediu Hill, Aroneanu Hill, Miroslava Hill, Galata Hill).

At the contact between the Jijia Hills and Central Moldavian Plateau the caprock structure generated an impressive escarpment: Iași Cuesta Escarpment, with an amplitude of up to $350 \mathrm{~m}$ (Băcăuanu et al., 1980; Ungureanu, 1993). Here in the Central Moldavian Plateau over the Bârnova-Muntele Formation there is a caprock of calcarenites, oolitic calcarenites and quartz arenites intercalated with sands and mudstones (Jeanrenaud and Saraiman, 1995; Brânzilă, 1999; Ionesi et al., 2005; Dill at al., 2011) which end the Bessarabian suite, the Repedea Formation (30 m thickness, with lateral facies variations toward south and east which show an increase in sands and sandstones and a decrease of limestones - Jeanrenaud and Saraiman, 1995; Ionesi et al., 2005).

Over the Bessarabian rocks, a $100 \mathrm{~m}$ transgressive thick Kersonian suite appear on top of the hills, which is composed mainly from sands (Ionesi et al., 2005). Toward south over the Kersonian suite there are the Meotian rocks from the Nuțasca-Ruseni Formation (Fig. 4). This formation is around 160 to $260 \mathrm{~m}$ thick and it is composed from sands and cineritic sandstones $(10-80 \mathrm{~m})$ and sands and mudstones (150-180 m) (Jeanrenaud and Saraiman, 1995; Ionesi et al., 2005). Because of the resistant caprock the hills from this area have relatively flat and elongated ridges, while the hillslopes have a relief of up to $250 \mathrm{~m}$.

The superficial deposits are various (Martiniuc and Băcăuanu, 1959; Cernătescu et al., 1966; Băcăuanu et al., 1980; Barbu et al., 1987): (i) deluvial deposits and altered bedrock on steep hillslopes where landslides are not present, (ii) mass movement deposits where landslide are present, (iii) fluvial terrace deposit (sands with basal gravels) covered by loess on cuesta dip slopes from Jijia Hills, (iv) soils or eluvial deposits on ridges and plateaus, in the Central Moldavian Plateau, (v) clayey and silty alluvial deposits on floodplains. 


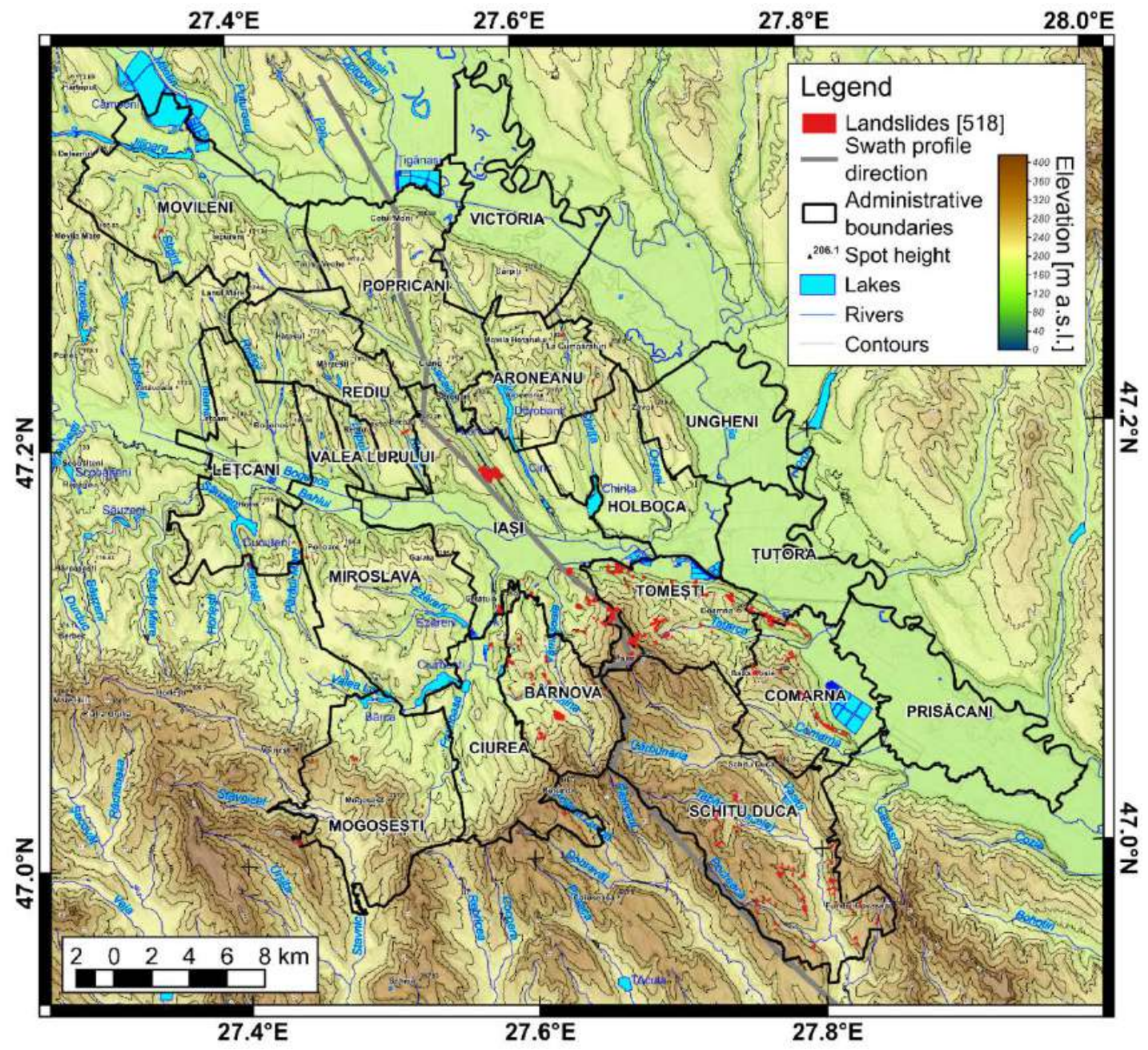

Figure 1 Geographic position of Iași Metropolitan Area

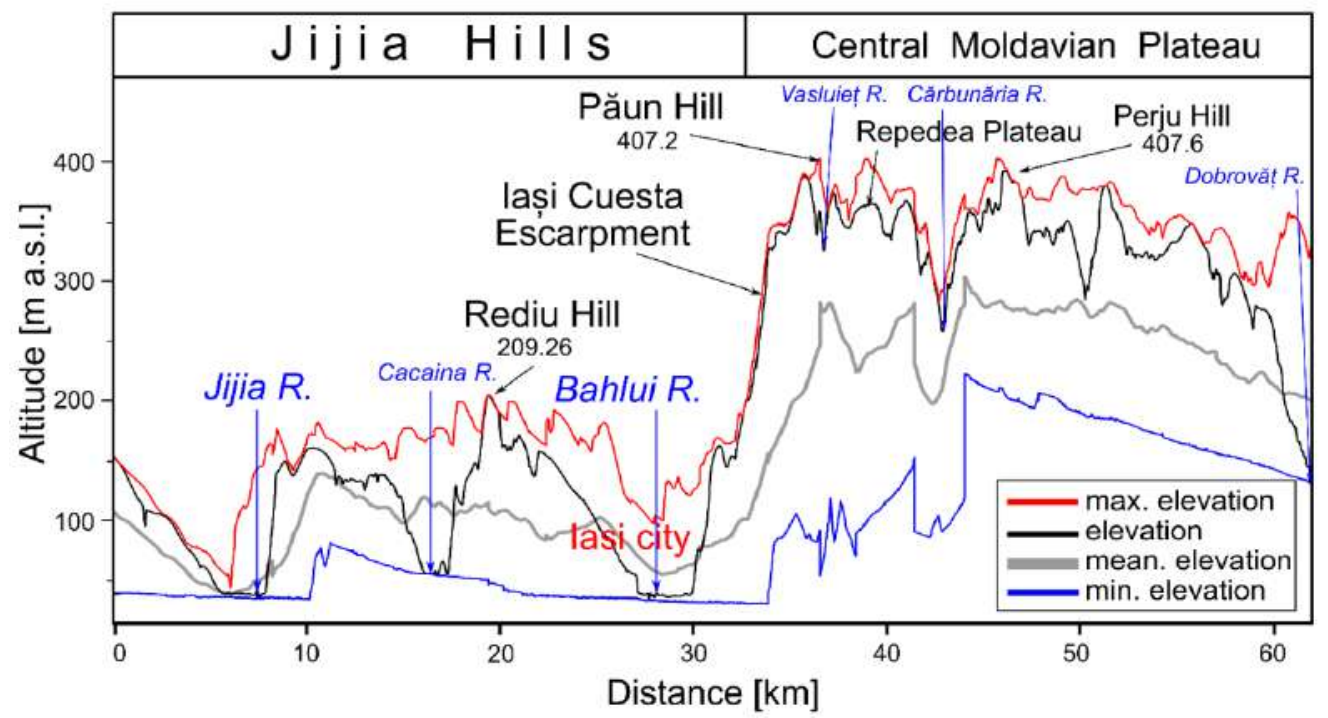

Figure 2 Swath profile (15 km wide) through the study area (the vertical scale is exaggerated in order to allow the recognition of all the elevation profiles) 


\subsection{Landslide history}

North-Eastern Romanian hilly area is well known for its relict and old landslides developed especially on cuesta scarp slopes (Niculiță and Mărgărint, 2014; Niculiță et al., 2016; Mărgărint and Niculiță, 2017), generating slope deposits which are very susceptible to landslide reactivations (Silion, 1965). Recent landslides which still keep the landslide morphologic elements under the current dry climatic conditions happened after Medieval times (Niculiță et al., 2016). Iaşi surroundings were covered by forests in the medieval times (Giurescu, 1976), especially toward south (Iaşi-Bârnova forest) and south-west (Căpoteştilor forest), but also toward east (Bîc forest), south-east (Bohotin forest) or north (Copou and Ciric forests - Tufescu, 1932) which were cleared in the modern period as the city extended from the Palatul Culturii fluvial terrace (Băcăuanu and Martiniuc, 1966) toward the surroundings (Tufescu, 1932). In this context we believe that the reactivations of the old and relict Holocene landslide (Martiniuc and Băcăuanu, 1982) bodies and scarps (Silion, 1965), while happening probably also during medieval times, became more frequent after, when the forest clearance and human pressure intensified ("Galata din Vale"/"Galata de Jos" Monastery which was affected by landslides between 1579 and 1582 - Grigoraş, 1943; Cârciuleanu, 1991; Ureche, 2017).

Areas with reactivations are known for Iași surroundings in the following locations: the Copou Hill north-eastern hillslope (1911, 1932-1933, 1934, 1940-1942, 1961，1969-1970, 1984，2017), the Păcurari neighborhood, the Șorogari Hill western hillslope (1969-1970), the Galata Hill northern hillslope (1932-1933, 1941-1942, 1960, 1970, 1971, 1973, 1974-1975, 1979), the Cârlig Hill western hillslope (1981), for Cetățuia (1979-1980) and the Bucium area (1973) as reported by various authors (Macarovici, 1942; Silion, 1965; Băcăuanu, 1970; Palade and Băcăuanu, 1971; Brişcan, 1980; Martiniuc and Băcăuanu 1982; Schram et al., 1977). In recent times landslide reactivations were reported in Todirel village (5 March 1999), Munteni Neighborhoud, Grădina Botanică, Șapte Oameni, Moara de Vânt. Beside these areas, where the landslide mechanism have a strong natural component, there are several places where the landslide mechanism is highly influenced by anthropic processes, especially along roads: on communal road DC49 toward Hadâmbu Monastery (2000 to 2017), Bahlui river bank (2015), on county road DJ248D in Bucium (2000-2010) and along the national road DN24 between Păun and Poieni (2005).

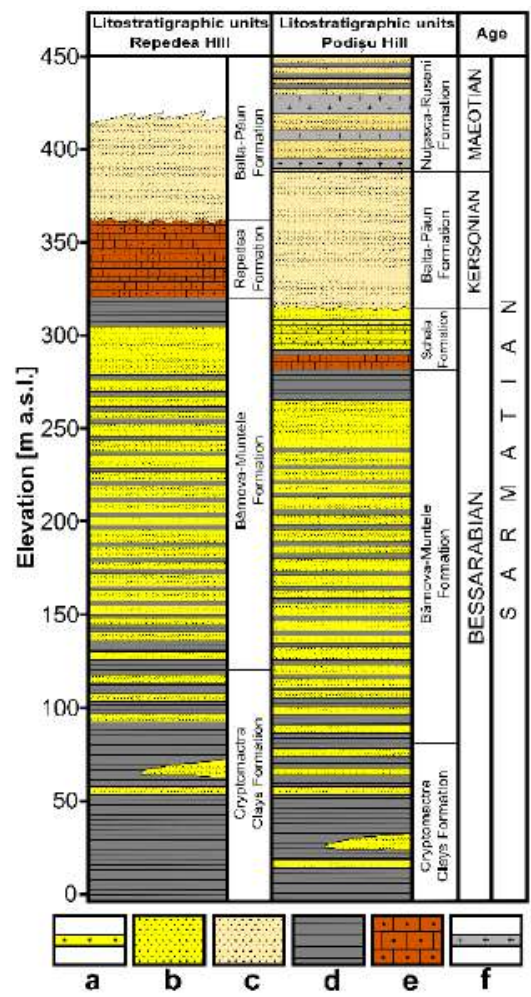

Figure 3 Lithostratigraphic columns of IMA geology (Jeanrenaud, 1971, Jeanrenaud and Saraiman, 1995; Brânzilă, 1998, 1999; Ionesi et al., 2005): a - sandstones, b - sands, c - deltaic sands, d - siltstones, e - oolitic limestones, $f$ - cinerites

A geomorphological landslide inventory for Iași municipality was prepared by Necula and Niculiță (2017) and a historical inventory for Iași County was prepared by Niculiță et al. (2017). The slow moving displacement rates were identified for the 20142017 period for the north-eastern hillslope of Copou Hill by Necula et al. (2017).

\section{Materials and methods}

\subsection{Materials}

Historical map sources (1:20000, 1:5000, 1:2000 topographic maps from the 1920-1960 period) were used to identify landslides which are older than 
1956 and LiDAR was used for the delineation of these landslides. Especially for the Copou Hillslope LiDAR data had to be interpreted also based on the historical reports.

The availability of four series of aerial images (1956-1964, 1971-1984, 2003-2005, 2008) and a 0.5 m spatial resolution LiDAR DEM acquired in 2012, allowed us to identify landslide events that happened between 1956 and 2015.

\subsection{Methods}

Landslide events were mapped as polygons only when all the landslide elements were identified on the aerial imagery or LiDAR (Ardizzone et al., 2007; Petschko et al., 2015; Niculiţă et al., 2016): crown and scarp, flanks, toe, rough landslide body (Fig. 5).
In unforested areas, these elements were quite easy to be depicted. In forested areas the field work and the use of LiDAR point clouds helped us to understand the morphology of the landslides. The typology was assessed using the Hungr et al. (2014) extension of the Cruden and Varnes (1996) classification. We identified the following types of landslides: (i) recent soil/earth planar/translational slides (type 12) develop mainly on steep hillslopes previously affected by old or relict landslides; (ii) on old landslide scarps, rotational soil/earth slumps are frequent (type 11); (iii) old landslide deposits with a mixture of clays, silts and sands or the sandy bedrock are affected by flowslides and earthflows (type 20 and 26).

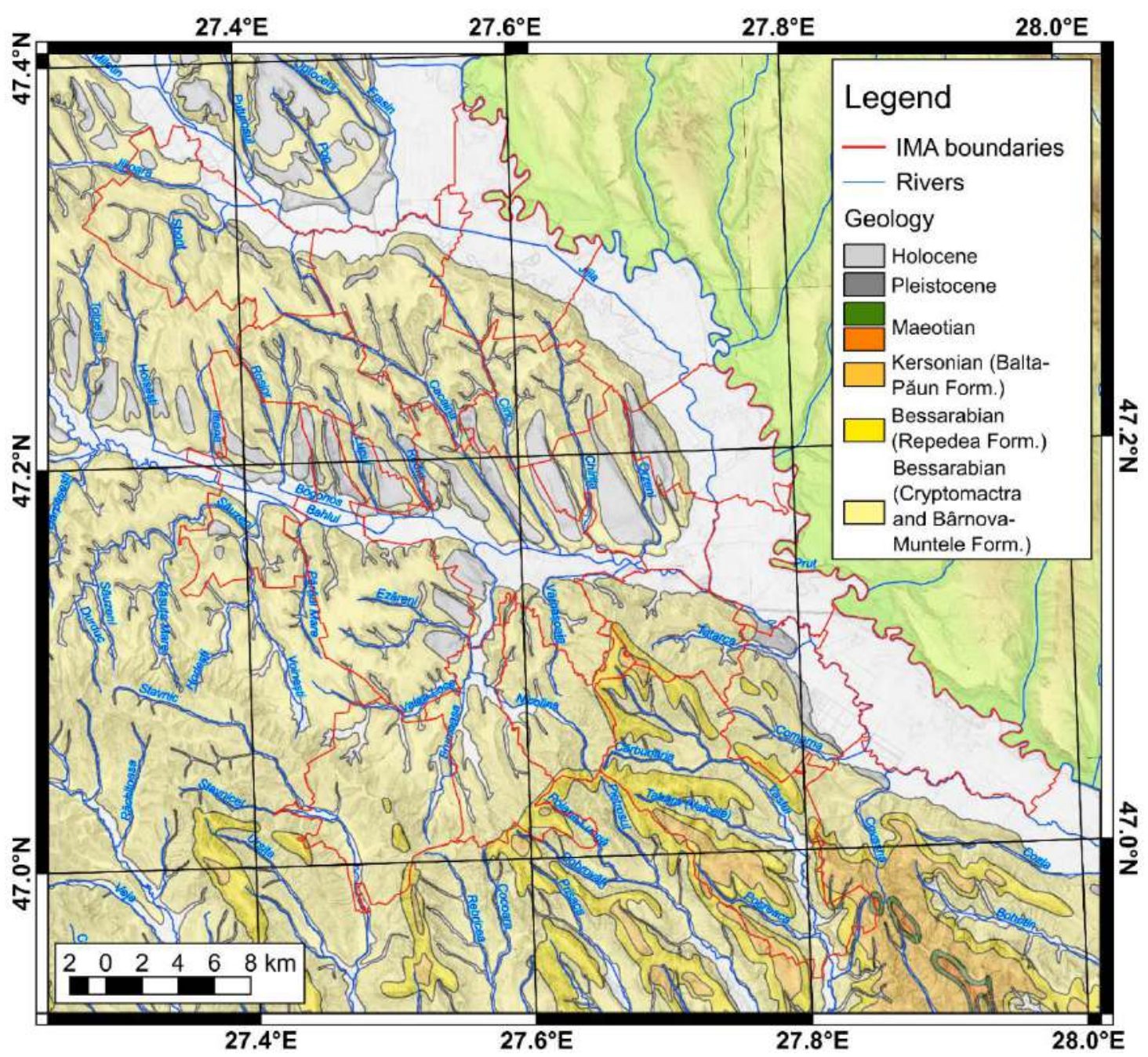

Figure 4 Geologic map of IMA (compiled after the 1:200 000 Geological Map of Romania, Saulea et al., 1966, completed with maps and information from Jeanrenaud and Saraiman, 1995, Brânzilă, 1998, 1999, Ionesi et al., 2005) 

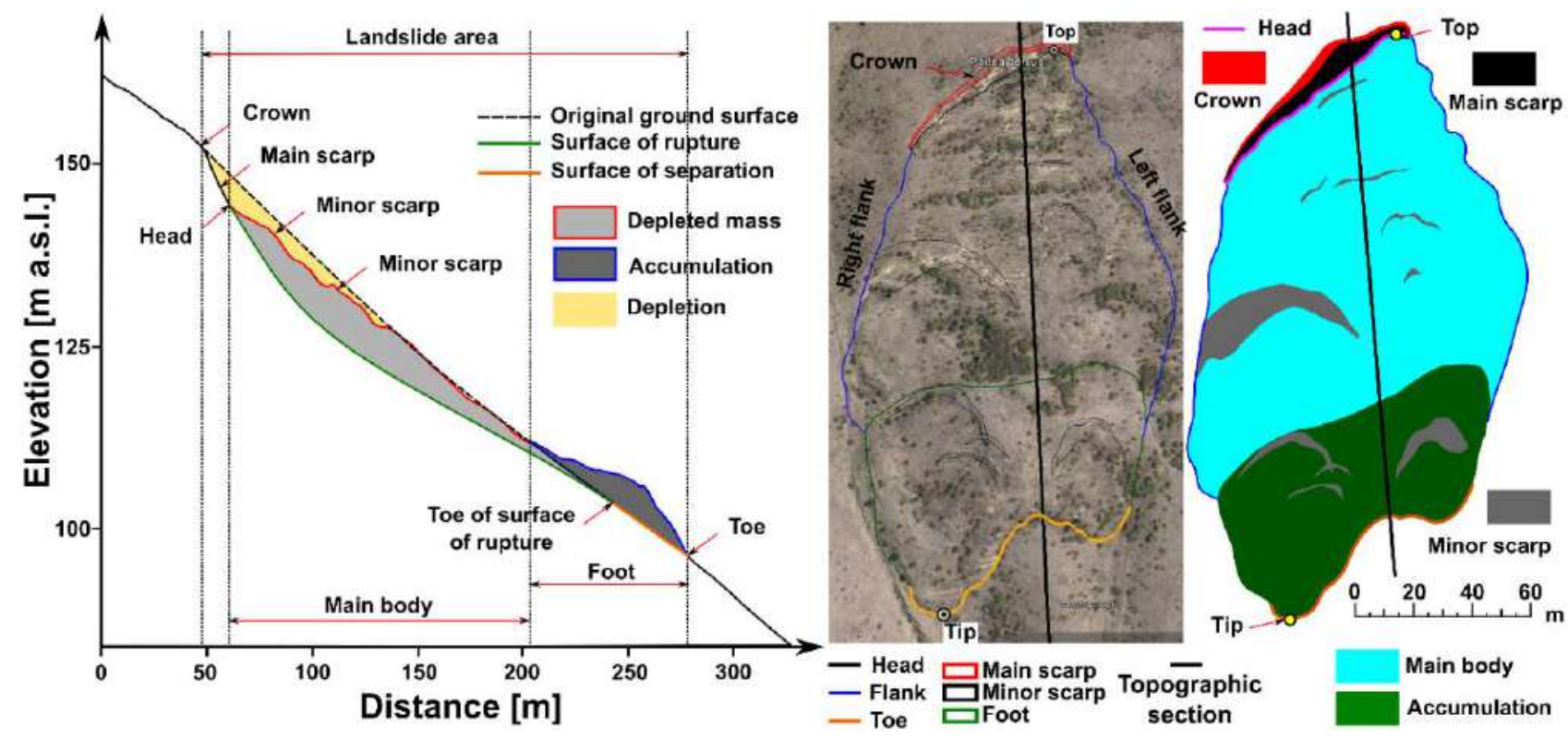

Figure 5 Landslide delineation elements for the post 1984 landslide localized on the northern hillslope of Miroslava Hill (the elements were considered regarding the Cruden and Varnes, 1996 work) on a topographic section (left), aerial imagery (center)

\section{Results and discussions}

We have identified and mapped 518 landslide events (Fig. 1). The majority of the identified landslides are translational slides (51.5\%). Slumps (rotational slides) and flowslides are the other type of landslides considering the frequency $(19.7 \%$ and $17 \%)$. Flows represent $11.8 \%$. The association of the process type with the displaced material is very hard to be performed because the slope deposits are very similar with the geological deposits.

The majority of the events appear on previous slided areas, as reactivations of the scarp or of the main body. Translational landslides are more frequent on old and relict landslide bodies, but flows are also present. Slumps (rotational failures) and flowslides are the most frequent on old and reactivated landslides scarps. Flows are also present along scarps. Some of the landslides that were triggered before or after 1964 and before 1984, were levelled after 1970 by the antierosional measures taken in the study area, so do not appear on the LiDAR dataset (Fig. 6 - 4th row).

The magnitude of the identified landslides is low (under $140000 \mathrm{~m}^{2}$ ), under what is considered in the literature magnitude 1 (Malamud et al., 2004), their length doesn't exceeding $700 \mathrm{~m}$ and with widths in general under $50-100 \mathrm{~m}$ (Fig. 7). The shape of the area frequency density is similar with that of landslide inventories triggered by specific events, situation which allows us to consider this landslide inventory to be representative for the present day conditions in the study area (Fig. 7) and to be usable in landslide susceptibility modelling and validation. The low magnitude and the fact that almost all the identified landslides happened outside populated areas show that landslides do not represent a real day by day threat for the population of IMA, but the situation could change in the future, considering the extension of the built up area (Iaţu and Eva, 2016; Doru, 2018) and the climate changes.

There are some exceptions, several areas being known for frequent reactivations: Copou north-east hillslope (Țicău and Sărărie area), Păcurari, Aurora, Șipoțel, Brândușa, Galata, Cetățuia, Cârlig, Todirel. The several notable exceptions generated population displacement during the last 100 years and still represent a real threat for the houses that remained. Considering that IMA is in continuous expansion of built area, the landslide susceptibility modelling (Necula and Niculiță, 2017) should be taken into account for planning purposes, since new built area will cover territories where these small magnitude landslides are frequent. 


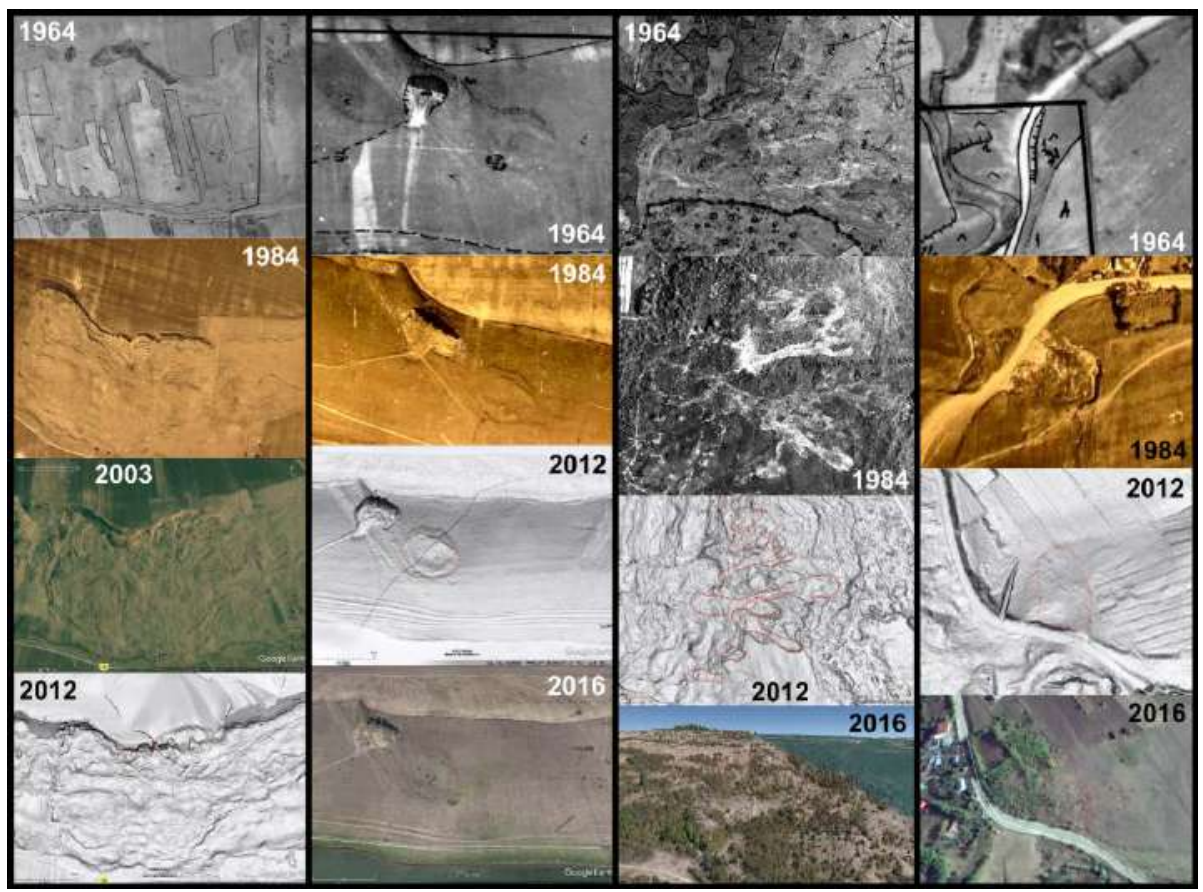

Figure 6 Landslide typology on various resources used for identification and mapping: slumps north of Rusenii Noi triggered after 1964 (1st row from left), translational slide triggered before 1964 (2nd row from left), flows and flowslides from Bucium hillslope triggered after 1964 (3rd row from left), translational slide south of Orzeni triggered after 1964

(4th row from left)

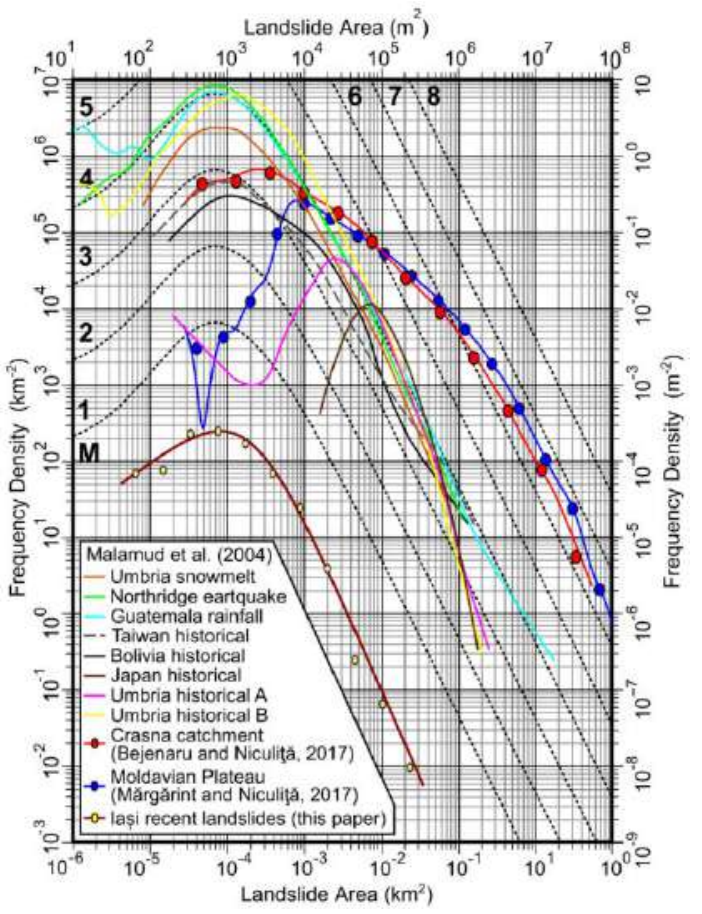

Figure 7 Landslide area frequency density for the produced landslide inventory and comparison with other inventories from the Moldavian Plateau (Bejenaru and Niculiţă, 2017; Mărgărint and Niculiţă, 2017) and around the world (Malamud et al., 2004)
A strong temporal pattern exist, the majority of the landslides appearing between 1956 and 1984 (74\%). The landslides which were triggered before 1956 but probably not before 1890-1920 (because the disturbances are not present of the topographic maps) represent $16 \%$, while those triggered after 1984 represent $10 \%$. The $1960-1990$ period is known to be a wet period, compared with the period after 1990, which is considered a dry period (Fig. 8 and 9). Future rainy period might increase the frequency of landslides in areas which today are considered stable.

The precondition factors of the recent landslides from Iaşi Metropolitan Area are the monoclinic and caprock morphostructure, the lithology (intercalations of clays and sands), the climate and the land use (Mărgărint and Niculiţă, 2017). The mean annual rainfall is increasing from Iaşi (102 m a.s.l. - over 550 $\mathrm{mm}$ ) to Bârnova (395 m a.s.l. - over $770 \mathrm{~mm}$ ), mainly because of orographic precipitation induced by the western air mases movement over the Central Moldavian Plateau (Roe, 2005; Mihăilă, 2006; Minea, 2012; Pelin, 2015). In the southern part of the study area the forest is dominant, while in the northern 
part of the study area the agricultural fields and the pastures are dominant. In the central part, in Iaşi Municipality there is a high density of built up areas (Doru, 2018).

The preparatory factors are the pre-existence of old and relict landslides (Niculiţă et al., 2016; Mărgărint and Niculiţă, 2017), the rainfall variation and the land use changes. Rainfall variation in the study area was mainly related to the increase of the rainfall quantity in May-July compared to the August-October, in 1891-1920, 1920-1935, 19401953, but especially after 1960, until 1991 (Pelin, 2015). The most frequent duration of consecutive years with rainfall excess is 2 years (Mihăilă, 2006). In the last two centuries the anthropic pressure increased, through forest clearance, agricultural fields, orchard, vineyard and settlement extension (Doru, 2018). The rainfall variability and the changes in land use affected especially the stability of the Holocene landslides scarps, where at the contact between the permeable fluvial terrace and loess deposits with the impermeable siltstones and mudstones important aquifers develop (Macarovici, 1942; Silion, 1965; Palade and Băcăuanu, 1971; Brişcan, 1980; Martiniuc and Băcăuanu 1982; Schram et al., 1977). The saturation of the materials from the base of the scarps and of the landslide body deposits generated the majority of the reactivations, and also controls the landslide type. Landslides under forests are in general of small magnitude and disturb the forest only in the scarp area, although especially in areas where anthropic disturbances appear important landslides were triggered (Horticulture Faculty event - Palade and Băcăuanu, 1971). Areas which are recently deforested very often supported landslide reactivations.

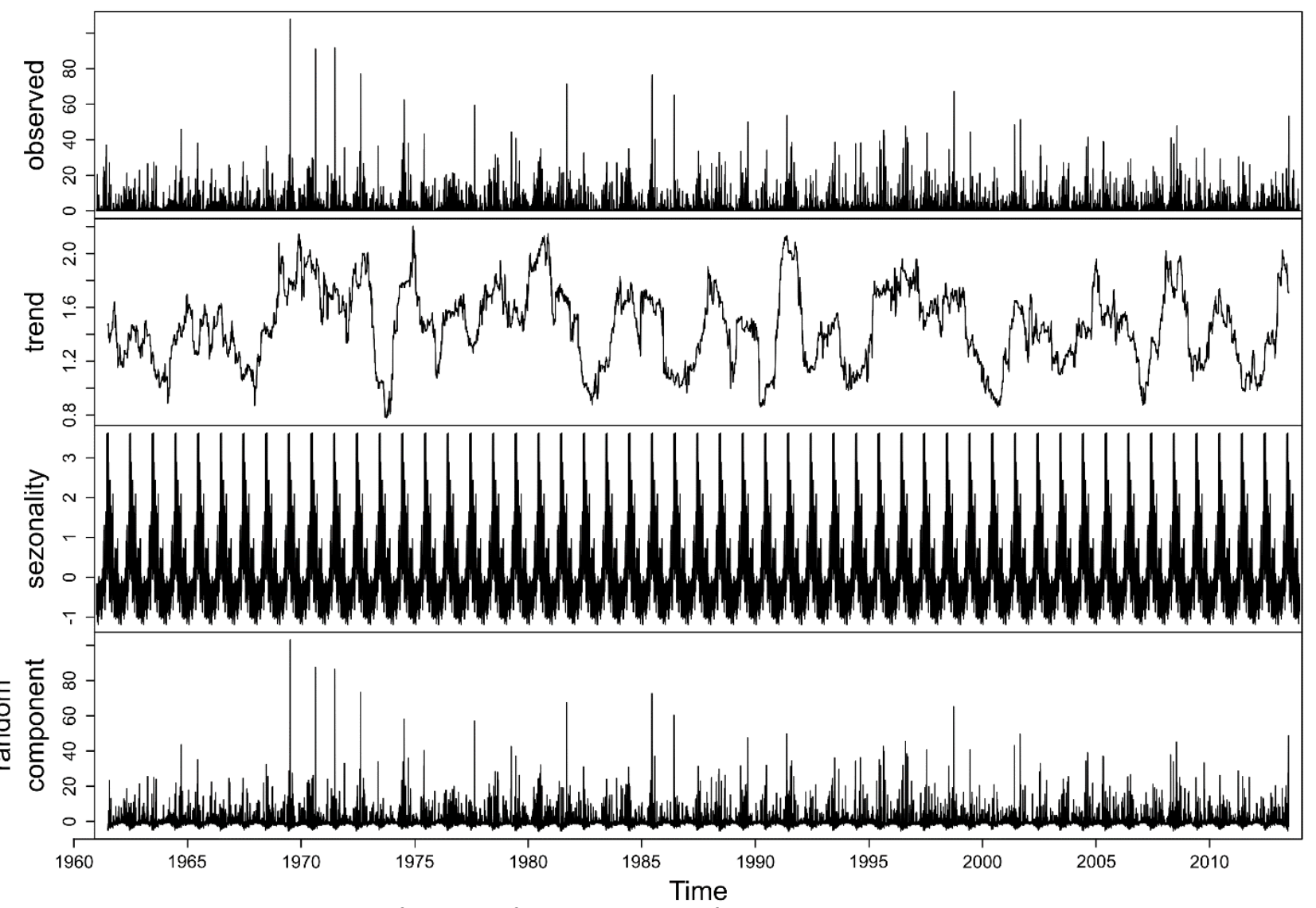

Figure 8 Additive decomposition of daily rainfall temporal data for Iași meteorological station, according to ROCADA dataset (Dumitrescu and Bîrsan, 2015) 


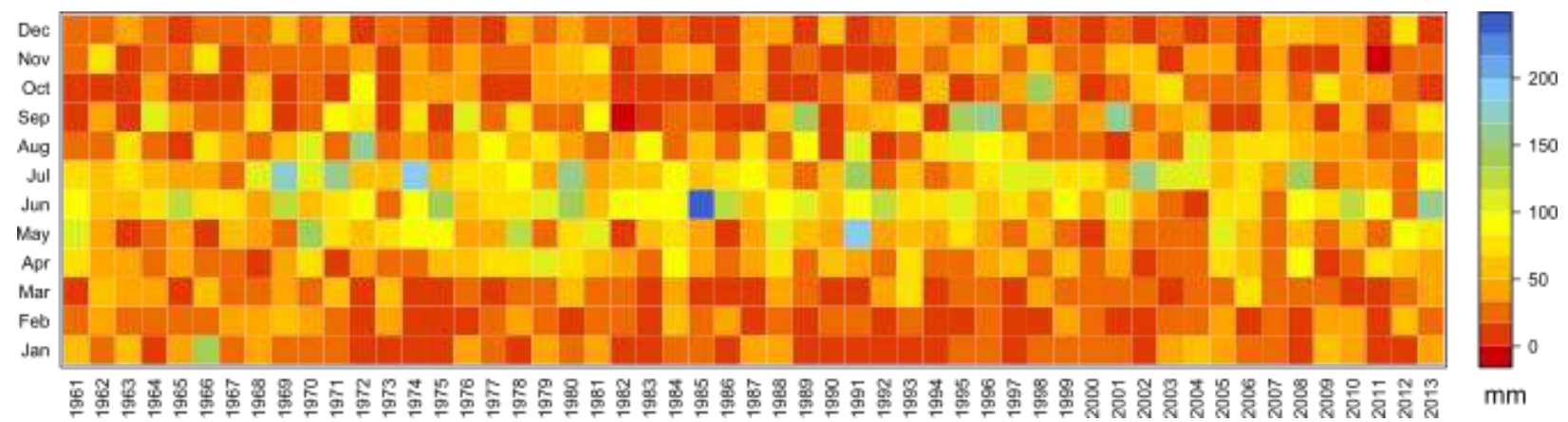

Figure 9 Mean monthly rainfall data for Iași Municipality, according to ROCADA dataset (Dumitrescu and Bîrsan, 2015)

\section{Conclusions}

We present a database of 518 landslides events from Iasi County, which happened in the last 100 years. For these events, the historical data, remote sensing data and the field evidences are enough to provide the full picture of the landslide typology and morphology, of the landslide conditional, preparatory and triggering factors, of landslide magnitude and temporal evolution, of immediate effects on humans and infrastructure and the implications on future human activity in the area.

Among the studied events the Copou hillslope, Iaşi city, is one of the most interesting case of landslide reactivations during the last 100 years, with more possible future reactivation events, and which generated the biggest damages, fortunately without human life loss. While some of the presented landslides affected human settlements and infrastructure, the majority are cases where the landslides happened outside settlements and infrastructure, but the extensions of the built up area inside the metropolitan borders is to be expected. Also, in the case of an increase in the amount of rainfall, the frequency of landslide events might also increase.

Landslide inventories which describe in depth landslide events, their spatial and temporal location, their causes and their effects are very important for landslide susceptibility modelling and validation and for vulnerability scenario assessment. This database and its possible extension to include more events is of crucial importance for the landslide hazard and risk modelling for Iaşi Metropolitan Area

\section{Acknowledgement}

This work was supported by a grant of Ministery of Research and Innovation, CNCS - UEFISCDI, project number PN-III-P1-1.1-PD-2016-0154, within PNCDI III. We are grateful to Prut-Bârlad Water Administration who provided us with the LIDAR data.

\section{References}

Alexander ED. 2005. Vulnerability to landslides. In: Glade T, Anderson MG, Crozier MJ (eds.): Landslide risk assessment. John Wiley, 175-198.

Ardizzone F, Cardinali M, Galli M, Guzzetti F, Reichenbach P. 2007. Identification and mapping of recent rainfallinduced landslides using elevation data collected by airborne Lidar. Natural hazards and earth system science, 7: 637-650. DOI: 10.5194/nhess-7-637-2007.

Băcăuanu V, Martiniuc C. 1966. Cercetări geomorfologice asupra teraselor din bazinul Bahluiului (Geomorphological research on Bahlui catchment river terraces). Analele Științifice ale Universității Alexandru Ioan Cuza din Iași, serie nouă, Secțiunea IIb, 12: 147-156 (in Romanian)

Băcăuanu V. 1968. Cîmpia Moldovei. Studiu geomorphologic (Moldavian Plain - geomorphological study). Editura Univ. Al. I Cuza, Iași, 221 p. (in Romanian)

Băcăuanu V.1970. Alunecările de teren din partea nordestică a Dealului Copou-Iași (The landslides from the north-western part of Copou Hilllsope - Iaşi). Analele Științifice ale Universității Alexandru Ioan Cuza din Iași, serie nouă, Secțiunea II, 16: 143-146 (in Romanian)

Băcăuanu V, Barbu N, Pantazică M, Ungureanu A, Chiriac D. 1980. Podișul Moldovei. Natură, om, economie (Moldavian Plateau - nature, human and economy). Scientific and encyclopedic Press București, 345 p. (in Romanian)

Barbu N, Ungureanu A, Apăvăloaiei M, Băcăuanu V, Erhan E, Giosu V, Gugiuman I, Lupu-Bratiloveanu N, Martiniuc C, Nimigeanu V, Pantazică M, Poghirc $P$, Schram M, Şandru I, Ungureanu I. 1987. Geografia Municipiului Iași (Iași Municipality Geography). 
Alexandru Ioan Cuza University of Iași Press. 311 p. (in Romanian)

Bejenaru A, Niculiță M. 2017. Landslide inventory of the Crasna catchment, Moldavian Plateau, Romania. In: Niculiță M, Mărgărint MC. (eds.): Proceedings of Romanian Geomorphology Symposium, vol. 1, Alexandru Ioan Cuza University of Iași Press Iași, 28-31. DOI: 10.15551/prgs.2017.28

Brânzilă M. 1998. Studiul geologic al Câmpiei Moldovei între Bârnova-Mădârjac și Ștefănești-Botoșani (The geological study of Moldavian Plain between Bârnova-Mădârjac and Ștefănești-Botoșani). 2 vol. Alexandru Ioan Cuza University of Iași. PhD thesis (in Romanian)

Brânzilă M. 1999. Geologia Câmpiei Moldovei (Geology of the Moldavian Plain). Corson Press Iași. 221 p. (in Romanian)

Brabb EE. 1991. The world landslide problem. Episodes, 14: $52-61$.

Brişcan A. 1980. Studiul alunecărilor de teren din zona Galata - Iaşi. Factorii potenţiali, tipuri şi indici caracteristici, corelaţii teritoriale. Implicaţii de ordin practic şi metodic (The study of landslides from galata - Iași area). Alexandru Ioan Cuza University of Iaşi, Dissertation (in Romanian)

Cârciuleanu I. 1991. Mănăstirea Galata (Galata Monastery). Moldavian and Bukowina Mitropoly Press Iaşi. 107 p. (in Romanian)

Carrara A, Merenda L. 1976. Landslide inventory in northern Calabria, southern Italy. Geological Society of America Bulletin, 87: 1153-1162. DOI: 10.1130/00167606(1976)87<1153:LIINCS > 2.0.CO;2

Carrara A, Crosta G, Frattini P. 2003. Geomorphological and historical data in assessing landslide hazard. Earth Surface Processes and Landforms, 28: 11251142. DOI: 10.1002/esp.545

Cernătescu A, Martiniuc C, Silion T, Ciubotaru V, Mihăilescu C. 1966. Contribuţie la studiul stabilităţii versanţilor din raza oraşului Iaşi (Contributions to the study of hillslope stability in Iași city). Buletinul Institutului Politehnic din Iaşi, serie nouă, XII(XVI)(3-4): 431-436 (in Romanian)

Crozier MJ, Glade T. 2005. Landslide hazard and risk: issues, concepts and approach. In: Glade T, Anderson MG, Crozier MJ. (eds.): Landslide risk assessment. John Wiley, 1-40.

Cruden DM, Varnes DJ. 1996. Landslide types and processes. In: Turner AK, Schuster RL. (eds.): Landslides, investigation and mitigation. Transportation Research Board Special Report 247, Washington D.C. pp 36-75.

Dill HG, Iancu GO, Ionesi V, Sârbu S, Balintoni I, Botz R. 2012. Petrography and mineral chemistry of Bessarabian siliciclastic rocks in the Eastern Carpathians
Foreland Basin (Romania and Republic of Moldova). Neues Jahrbuch für Geologie und Paläontologie Abhandlungen, 263(3): 199-226. DOI: 10.1127/00777749/2012/0224

Doru CS. 2018. Analiza spatială a schimbărilor de utilizare a terenului din judeţul Iaşi în secolele XX-XXI. Alexandru Ioan Cuza University of Iaşi. Phd Thesis. (in Romanian)

Dumitrescu M, Bîrsan MV. 2015. ROCADA: a gridded daily climatic dataset over Romania (1961-2013). Natural Hazards 78(2): 1045-1063. DOI: 10.1007/s11069-0151757-z00

Giurescu C. 1976. Istoria pădurii româneşti din cele mai vechi timpuri până astăzi (The history of Romanian forests from ancient times until today). Ceres Press Bucureşti, 391 p. (in Romanian)

Grigoraş N. 1943. Mînăstirea Galata (Galata Monastery). Studii şi cercetări istorice 1(1): 1-85 (in Romanian)

Guzzetti F, Carrara A, Cardinali M, Reichenbach P. 1999. Landslide hazard evaluation: a review of current techniques and their application in a multi-scale study, Central Italy. Geomorphology, 31(1-4): 181-216. DOI: 10.1016/S0169-555X(99)00078-1

Guzzetti F, Mondini AC, Cardinali M, Fiorucci F, Santangelo $\mathrm{M}$, Chang $\mathrm{K}-\mathrm{T}$. 2012. Landslide inventory maps: New tools for an old problem. Earth-Science Reviews, 112: 42-66. DOI: 10.1016/j.earscirev.2012.02.001

Guzzetti F. 2006. Landslide Hazard and Risk Assessment. Mathematisch-Naturwissenschaftlichen Fakultät der Rheinischen Friedrich-Wilhelms-Universität University of Bonn. PhD thesis.

Hungr O, Leroueil S, Picarelli L. 2014. The Varnes classification of landslide types, an update. Landslides, 11: 167-194. DOI: 10.1007/s10346-013-0436-y

Iaţu C, Eva M. 2016. Spatial profile of the evolution of urban sprawl pressure on the surroundings of Romanian cities (2000-2013). Carpathian Journal of Earth and Environmental Sciences, 11(1): 79-88.

Ionesi L, Ionesi B, Roșca V, Lungu A, Ionesi V. 2005. Sarmațianul mediu și superior de pe Platforma Moldovenescă (Middle and Upper Sarmatian on Moldavian Platform). Romanian Academy Press Bucureşti. 559 p. (in Romanian).

Ioniţă I. 2000. Relieful de cueste din Podişul Moldovei (Cuesta landforms from Moldavian Plateau). Corson Press Iaşi. 108 p. (in Romanian)

Jeanrenaud P. 1971. Harta geologică a Moldovei Centrale dintre Siret și Prut (Geological map of the Central Moldavia between Siret and Prut). Analele Stiințifice ale Universității Alexandru Ioan Cuza din Iași, Serie nouă, Secțiunea II, 17: 65-68 (in Romanian)

Jeanrenaud P, Saraiman A. 1995. Geologia Moldovei Centrale dintre Siret și Prut (Geology of the Central Mol- 
davia between Siret and Prut). Alexandru Ioan Cuza University of Iași Press Iaşi. 186 pp. (in Romanian)

Mărgărint MC, Niculiţă M. 2017. Landslide type and pattern in Moldavian Plateau, NE Romania. In: Rădoane M, Vespremeanu-Stroe A. (eds.): Landform Dynamics and Evolution in Romania. Springer Geography, Springer Cham, 271-304. DOI: 10.1007/978-3-31932589-7_12

Macarovici N. 1942. Observațiuni asupra alunecărilor de teren de la Iași din primăvara anului 1942 (Comments on landslides from Iași in the spring of 1942). Revista Stiințifică V. Adamachi, 28(2-3): 1-4 (in Romanian)

Malamud B, Turcotte DL, Guzzetti F, Reichenbach P. 2004. Landslide inventories and their statistical properties. Earth Surface Processes and Landforms, 29(6): 687711. DOI: 10.1002/esp.1064

Martiniuc C, Băcăuanu V. 1959. Harta geomorfologică a orașului Iași (Geomorphological map of Iași city). Analele Științifice ale Universitătii Alexandru Ioan Cuza din Iași, Serie nouă, Secțiunea II, 5: 183-190 (in Romanian)

Martiniuc C, Băcăuanu V. 1982. Deplasările de teren din municipiul Iași și împrejurimi (Mass movements from the city of Iaşi and its surroundings). Buletinul Societății de Științe Geografice, 6: 152-158 (in Romanian)

Martiniuc C, Safca M, Băcăuanu V, Barbu A, Pantazică M. 1956. Contribuție la studiul hidrogeologic al regiunii orașului Iași (Contribution to the hydrogeological study of the Iasi city region). Probleme de Geografie, 3: 61-95 (in Romanian)

Mihăilă D. 2006. Câmpia Moldovei. Studiu climatic (Moldavian Plain. Climatic study). Suceava University Press Suceava. 465 p. (in Romanian)

Minea I. 2012. Bazinul hidrografic Bahlui - studiu hidrologic (Bahlui river catchment - hydrological study). Alexandru Ioan Cuza University of Iași Press Iaşi. 334 p. (in Romanian)

Necula N, Niculiță M. 2017. Landslide reactivation susceptibility modelling in Iași Municipality. Revista de Geomorfologie, 19: 101-117. DOI: 10.21094/rg.2017.021

Necula N, Niculiță M, Tessari G, Floris M. 2017. InSAR analysis of Sentinel-1 data for monitoring landslide displacement of the north-eastern Copou hillslope, Iași city, Romania. In: Niculiță M, Mărgărint MC. (eds.): Proceedings of Romanian Geomorphology Symposium, vol. 1, 11-14 May 2017, Alexandru Ioan Cuza University of Iași Press, Iași, 85-88. DOI: 10.15551/prgs.2017.85

Niculiţă M. 2011. A landform classification schema for structural landforms of the Moldavian platform (Romania). In: Hengl T, Evans IS, Wilson JP, Gould M. (eds.): Geomorphometry, Redlands, CA, 129-132.
http://geomorphometry.org/system/files/Niculita2011geomorphometry.pdf

Niculiță M, Mărgărint MC. 2014. Landslide inventory for the Moldavian Plateau. In: Proceedings of International Conference Analysis and Management of Changing Risks for Natural Hazards, 18-19 Nov 2014, Padua, Italy. p 10

http://www.changesitn.eu/Portals/0/Content/2014/Fi nal\%20conference/abstracts/AP3_Abstract_Niculita.p df

Niculiţă M, Mărgărint C, Santangelo M. 2016. Archaeological evidence for Holocene landslide activity in the Eastern Carpathian lowland. Quaternary International, 415(10): 175-189. DOI:10.1016/j.quaint.2015.12.048

Niculiță M, Andrei A, Lupu C. 2017. The landslide database of the North-Eastern Romania. In: Niculiță M, Mărgărint MC (eds.): Proceedings of Romanian Geomorphology Symposium, vol. 1, 11-14 May 2017, Alexandru Ioan Cuza University of Iași Press, Iași, 8184. DOI: $10.15551 /$ prgs.2017.81

Palade L, Băcăuanu V. 1971. Contribuţii la studiul alunecărilor de teren din partea de nord-est a Dealului Copou-Iaşi (Facultatea de Horticultură) (Contributions to the study of landslides in the northeastern part of the Copou-Iasi Hill). Lucrări ştiinţifice. Seria agronomie - horticultură, 1: 197-202 (in Romanian)

Pelin L-I. 2015. Fenomenul de secetă din Câmpia Moldovei (Drought phenomena from Moldavian Plain). Alexandru Ioan Cuza University of Iaşi. PhD thesis (in Romanian)

Petschko H, Bell T, Glade T. 2015. Effectiveness of visually analyzing LiDAR DTM derivatives for earth and debris slide inventory mapping for statistical susceptibility modeling. Landslides, 13: 857-872. DOI: 10.1007/s10346-015-0622-1

Reid LM. 1998. Calculation of average landslide frequency using climatic records. Water Resources Research, 34(4): 869-877.

Roe G.H. 2005. Orographic precipitation. Annual Review of Earth and Planetary Sciences, 33: 645-71. DOI: 10.1146/annurev.earth.33.092203.122541

Saulea E, Săndulescu J, Bratu E. 1966. Harta geologică 1:200 000, 14 Iași, foaia L-35-X și L-35-XI (1:200 000 Geological Map - Iași Sheet). State Committee of Geology, Geological Institute. București (in Romanian)

Schram M, Pantazică M, Martiniuc C. 1977. Aspecte hidrogeologice din zona Municipiului Iași și împrejurimi (Hydrogeological aspects of Iaşi Municipality and its surroundings). Analele Stiințifice ale Universității Alexandru Ioan Cuza din Iași, Serie nouă, Secțiunea II, 32: 107-113 (in Romanian) 
Silion T. 1965. Contribuţii la studiul stabilităţii versanţilor Dealului Copou în raza oraşului Iaşi (Contributions to the study of stability of the Copou Hill slopes in the city of Iasi). Polytechnical Institute Iaşi. PhD thesis (in Romanian)

Tufescu V. 1932. Asupra aşezării şi desvoltării oraşului Iaşi (On the settlement and development of Iasi city). Buletinul Societăţii Regale Române de Geografie, 52: 302-313 (in Romanian)

Van Westen CJ, van Asch TWJ, Soeters R. 2006. Landslide hazard and risk zonation - why is it still difficult? Bul- letin of Engineering Geology and the Environment, 65: 167-184. DOI: 10.1007/s10064-005-0023-0

Varnes DJ. 1984. Landslide hazard zonation: a review of principles and practice. UNESCO Press Paris, $63 \mathrm{p}$.

Ungureanu A. 1993. Geografia podișurilor și cîmpiilor României (The geography of Romanian plateaus and plains). Alexandru Ioan Cuza University of Iași Press Iași. 245 p. (in Romanian)

Ureche G. 2017 Letopiseţul Tării Moldovei. Scriptorum (in Romanian) 